\title{
Effects of Fasting on Gluconeogenic Enzymes in the Ovine Fetus
}

\author{
JAMES A. LEMONS, HELEN C. MOOREHEAD, AND GEORGE P. HAGE \\ Section of Neonatal-Perinatal Medicine, Department of Pediatrics, Indiana University School of Medicine and \\ the James Whitcomb Riley Hospital for Children, Indianapolis, Indiana 46223
}

\begin{abstract}
Fetal and maternal sheep were studied to determine whether changes in gluconeogenic enzyme activities could be detected in the liver and/or kidney associated with maternal nutritional deprivation. Thirteen ewes and 16 fetuses were sacrificed in the fed state, while 13 ewes with 17 fetuses were sacrificed after 5 days of fasting, all at 125 days gestation (term $=147$ days). Fetal weight was decreased in the fasted versus fed group $(2.86 \pm 0.56$ versus $3.61 \pm 0.58 \mathrm{~kg}, p<0.001$ ). Tissues were analyzed for glucose-6-phosphatase, fructose-1,6-diphosphatase, pyruvate carboxylase, phosphoenolpyruvate carboxykinase, glutamate oxaloacetate aminotransferase, and glutamate pyruvate aminotransferase. In maternal liver, four of the six enzymes increased significantly during fasting, whereas none of the enzymes increased in maternal kidney. In fetal hepatic tissue, five of the six enzymes (with the exception of pyruvate carboxylase) increased during maternal fasting and three of the enzymes increased in renal tissue. These data are consistent with the potential for increased rates of gluconeogenesis in the ovine fetus during periods of compromised maternal nutrition. (Pediatr Res 20: 676679, 1986)
\end{abstract}

\section{Abbreviations}

GP, glucose-6-phosphatase

FDP, fructose diphosphatase

PC, pyruvate carboxylase

PEPCK, phosphoenolpyruvate carboxykinase

GOT, glutamate oxaloacetate transaminase

GPT, glutamate pyruvate transaminase

SDS, author define

TCA, trichloroacetic acid

Glucose acquired transplacentally is the principal substrate for the mammalian fetus. Available data indicate that the quantity of glucose utilized by the normal growing ovine fetus is approximately the same as the amount of glucose supplied to the fetus from the mother via the placenta (1). It has also been clearly demonstrated that the amount of glucose provided to the fetus from the mother is directly related to the maternal plasma glucose concentration (2). In other words, if the maternal glucose level decreases, as occurs during fasting, the exogenous supply of glucose to the fetus decreases proportionately. If energy requirements as reflected by oxygen consumption do not decrease (3), then the fetus must seek alternate energy substrate to compensate

Received December 10, 1985; accepted March 11, 1986

Send correspondence and requests for reprints to James A. Lemons, M.D. Department of Pediatrics, Indiana University School of Medicine, 72 Barnhill Drive, Indianapolis, IN 46223.

Supported by NIH Grant PHS R01-14820-04. for the decreased supply of glucose. Considerable controversy has persisted concerning the ability of the fetus to manufacture new glucose from alternate substrates during such periods of compromised exogenous glucose supply (4). While this controversy continues, recent data, utilizing sophisticated steady state radioactive tracer infusions into the chronic sheep preparation, suggest that gluconeogenesis may occur under such situations (1). Supporting this observation, Stevenson et al. (5) previously demonstrated that the enzymatic machinery to manufacture glucose from alternate substrate is present in the developing ovine fetus. The present study was undertaken to determine whether activities of enzymes determined in vitro may reflect the physiologic changes (or flux of substrate) which have been observed in vivo during periods of compromised maternal nutrition. We hypothesized that if gluconeogenesis is occurring at a substantial rate within the fetus during a maternal fast, this would be reflected in a significant increase in the activities of the gluconeogenic enzymes in fetal tissues.

\section{MATERIALS AND METHODS}

For this investigation, 26 time-dated pregnant ewes of Suffolk breed were obtained. Thirteen ewes were fasted (with free access to water) for 5 days beginning at 120 days gestation. The remaining 13 were allowed to continue to feed ad libitum. All animals were then sacrificed at an estimated date of confinement of 125 days (term $=147$ days). At the time of sacrifice the animals were anesthetized with intravenous pentobarbital and a midline laparotomy performed. The fetus was rapidly exteriorized and the liver and kidneys immediately removed. A section of maternal liver and kidney were also obtained. The time required for tissue collection by the freeze-clamp method and processing was less than $5 \mathrm{~min}$ from the beginning of the abdominal incision.

Each tissue was subsequently assayed for the following enzymes: GP (EC 3.1.3.9), FDP (EC 3.1.3.11), PC (EC 6.4.1.1), PEPCK (EC 4.1.1.32), GOT (EC 2.6.1.1), and GPT (EC 2.6.1.2).

Tissue preparation. Tissue samples were collected by the freeze clamp method, and stored at $-70^{\circ} \mathrm{C}$ until analysis for GP, FDP, GOT, and GPT. For PEPCK and PC assays, fresh tissue samples were placed into four volumes of cold $0.2 \mathrm{M}$ sucrose buffer containing $20 \mathrm{mM}$ triethanolamine, $1 \mathrm{mM}$ GSH, and $1 \mathrm{mM}$ EDTA at $\mathrm{pH}$ 7.5. Small amounts of protease inhibitors $(0.5 \mu \mathrm{M}$ Leupeptin, $0.5 \mu \mathrm{M}$ Pepstatin A, and $0.5 \mathrm{mM}$ TLCK) were added. The tissue was homogenized in a Ten Broeck hand homogenizer and centrifuged at $100,000 \times g$ for $30 \mathrm{~min}$ at $2^{\circ} \mathrm{C}$. The particulate fraction was suspended in buffered sucrose and freeze-dried. Both the supernatant fraction and the lyophilized particulate fraction were stored then at $-70^{\circ} \mathrm{C}$ until enzyme analysis.

$G P$. Enzyme activity was assayed in homogenized tissues according to the procedure described by Wagle (6). Approximately $400 \mathrm{mg}$ tissue were homogenized in $3 \mathrm{ml}$ of ice cold water. The homogenate was then diluted to $20 \mathrm{ml}$ with ice cold water and assayed within 20 minutes. The assay medium contained $0.4 \mathrm{ml}$ 
of $0.1 \mathrm{M}$ citrate buffer ( $\mathrm{pH} 6.7$ ) and $0.5 \mathrm{ml}$ of $0.04 \mathrm{M}$ GP. The reaction was started by the addition of $0.1 \mathrm{ml}$ of homogenate at $37^{\circ} \mathrm{C}$. Incubation was for 0 and $10 \mathrm{~min}$ and the reaction was stopped by the addition of $1 \mathrm{ml}$ of $10 \%$ (w/v) TCA. Substrate blanks were also incubated at $37^{\circ} \mathrm{C}$ for 0 and $10 \mathrm{~min}$. After centrifugation, $1 \mathrm{ml}$ of the supernatant was analyzed for inorganic phosphate by the method of Fiske and Subbarow (7).

$F D P$. Livers were homogenized in ice-cold $1 \mathrm{M}$ tris-HCl buffer, $\mathrm{pH} 7.5$, for 2 min with the Ten Broeck tissue grinder. Between $60-90 \mathrm{mg}$ of tissue were used to make $10 \mathrm{ml}$ of homogenate. Homogenates were then centrifuged at $9,000 \times g$ for $10 \mathrm{~min}$ at $4^{\circ} \mathrm{C}$ in the Sorvall $\mathrm{RC} 2-\mathrm{B}$ centrifuge. Enzyme activity in the supernatant solution was assayed at $30^{\circ} \mathrm{C}$ by the spectrophotometric procedure of Bergmeyer as follows: the reaction mixture in a cuvette contained $150 \mu \mathrm{mol}$ of tris- $\mathrm{HCl}$ buffer, $\mathrm{pH} \mathrm{7.5,10}$ $\mu \mathrm{mol}$ of $\mathrm{MgCl}_{2}, 0.5 \mu \mathrm{mol}$ of NADP, $24 \mu \mathrm{mol}$ of mercaptoethanol, $3.5 \mathrm{U}$ of phosphoglucose isomerase, $0.7 \mathrm{U}$ of GP dehydrogenase, $0.5 \mu \mathrm{mol}$ of FDP and $100 \mu \mathrm{l}$ of sample. The final volume was 1 $\mathrm{ml}$. The change in the extinction per minute is used for the calculation of the enzyme activity (8).

$P G$. The lyophilized particulate fraction was rehomogenized in $1 \mathrm{ml}$ of cold water and $10 \mu \mathrm{l}$ of $1 \%$ SDS (maternal sample) or $10 \mu \mathrm{l}$ of $0.5 \%$ SDS (fetal sample) (9). Reaction mixture contained $25 \mu \mathrm{mol}$ of tris- $\mathrm{HCl}$ buffer, $\mathrm{pH} 7.4,10 \mu \mathrm{mol}$ of pyruvate, 2.5 $\mu \mathrm{mol}$ of ATP, $5 \mu \mathrm{mol}$ of $\mathrm{MgCl}_{2}, 0.75 \mu \mathrm{mol}$ of acetyl CoA, 50 $\mu \mathrm{mol}(2 \mu \mathrm{Ci})$ of $\mathrm{NaH}^{14} \mathrm{CO}_{3}, 0.1 \mathrm{ml}$ of homogenate, and enough water to make the final volume $1 \mathrm{ml}$. After incubating for 10 min at $37^{\circ} \mathrm{C}$, the reaction was stopped by the addition of $0.5 \mathrm{ml}$ of $10 \%(\mathrm{w} / \mathrm{v})$ TCA. Controls, consisting of the above system minus the Acetyl CoA and ATP, were also incubated for $10 \mathrm{~min}$ at $37^{\circ} \mathrm{C}$. After centrifugation, any remaining ${ }^{14} \mathrm{CO}_{2}$ was removed by bubbling unlabeled $\mathrm{CO}_{2}$ through the supernatant for $3 \mathrm{~min}$ and $1 \mathrm{ml}$ portion of the solution was counted in a Beckman model LS 7800 liquid scintillation spectrometer with Aquasol as solvent.

$P E P C K$. PEPCK activity was determined by measuring ${ }^{14} \mathrm{C}$ incorporation in the following reaction mixture: imidazole $\mathrm{HCl}$ buffer (pH 6.6) at $100 \mathrm{mM}, \mathrm{MnCl}_{2}$ at $2 \mathrm{mM}, \mathrm{NADH}$ at $2.5 \mathrm{mM}$, GSH at $1.0 \mathrm{mM}$, IDP at $1.25 \mathrm{mM}$, PEP at $1.5 \mathrm{mM}$, and $\mathrm{NaH}^{14} \mathrm{CO}_{3}$ at $50 \mathrm{mM}(2 \mu \mathrm{Ci} / \mathrm{ml})(9)$. Prior to the addition of homogenate, SDS was added to the homogenate at concentrations of $0.063 \mathrm{mg} / \mathrm{ml}$ for fetal and $0.125 \mathrm{mg} / \mathrm{ml}$ for maternal homogenate. The total reaction mixture was $0.5 \mathrm{ml}$ and the reaction was terminated at $10 \mathrm{~min}$ by adding $0.25 \mathrm{ml} 10 \%$ TCA. Zero time samples were prepared as above with the addition of TCA prior to the addition of $\mathrm{NaH}^{14} \mathrm{CO}_{3}$. Following centrifugation the excess ${ }^{14} \mathrm{C}$ was removed by bubbling $\mathrm{CO}_{2}$ through the solution for $3 \mathrm{~min}$. Five-tenths $\mathrm{ml}$ of the final solution was counted in a Beckman LS 7800 scintillation counter.

GOT and GPT. Activities of both of these enzymes were determined by following the rate of NADH oxidation at $30^{\circ} \mathrm{C}$ as described by Bergmeyer and Bernt (10).

In addition to the standard assays for these enzymes, preliminary studies were undertaken for two of the enzymes in order to assess: 1) reproducibility of the method; 2) the effect of longterm freezing of the tissues on recovery of enzyme activity; 3 ) the effects of immediate versus delayed freezing on enzyme activity; and 4) distribution of enzyme activity through the liver tissue. In performing these assays, both intra- and interassay variability were assessed for GP by performing multiple determinations on the same homogenate within the same assay on a given day and by reassaying the same homogenate in sequential assays. The effect of long-term freezing was assessed for GOT by determining enzyme acivity at approximately monthly intervals over an 8-month period. The effect of immediate freezing by submerging the tissue in liquid nitrogen was compared with the freeze clamp method, as well as with gradual freezing by placing the tissue in the $-70^{\circ} \mathrm{C}$ freezer after allowing a $10 \mathrm{~min}$ period of the tissues sitting at room temperature. Finally the cross-sectional studies were performed by slicing liver tissue in coronal cuts, freezing each slice, and then assaying in multiple sites across that section. This included both the left and right lobes of the liver.

Chemicals. GP, 1-amino-2-naphthol-4-sulfonic acid, mercaptoethanol, phosphoglucose isomerase (EC 5.3.1.9), GP dehydrogenase (EC 1.1.1.49), FDP, L-aspartic acid, L-alanine, 2-oxoglutarate, malic dehydrogenase (EC 1.1.1.37) in glycerol, lactic dehydrogenase (EC 1.1.1.27) in glycerol, leupeptin, pepstantin A, TLCK, glutathione, phosphoenolpyruvate, and pyruvate were obtained from the Sigma Chemical Co., St. Louis, MO; ATP, ITP, NADP, NADH were obtained from Boehringer Mannheim Biochemicals, Indianapolis, IN; and $\mathrm{NaH}^{14} \mathrm{CO}_{3}(1 \mathrm{mCi} / \mathrm{ml})$ was obtained from New England Nuclear, Boston, MA.

\section{RESULTS}

Intraassay variability for GP in hepatic tissue was determined on 24 separate homogenates prepared from the same tissue sample. Coefficient of variation for this assay was $7.6 \%$. Interassay variability was determined on 24 samples prepared from the same homogenate and performed in different assays over an 8 -wk period. Interassay coefficient of variability was $12.6 \%$.

The distribution of GP activity in liver was determined as described in "Materials and methods." There was no evidence of predictable or significant variation in enzyme activity over the cross-sections of liver studied. Four or five separate sites were assayed in each of four fetal and maternal livers in this study.

Three separate freezing techniques were studied by comparing activities measured on the same tissue samples treated with either freeze clamping, immediate submersion in liquid nitrogen, or by leaving at room temperature for $10 \mathrm{~min}$ and then placing in the $-70^{\circ} \mathrm{C}$ freezer. Results indicated no difference in GP activity assayed from tissues processed in any of these manners.

Stability of the tissue samples was evaluated by assaying the same liver and kidney preparation on day 1 of collection, and then $2 \mathrm{wk}, 1$ month, 4 months, and 8 months following tissue sampling. Five separate tissue samples were assayed over the 8month period. No significant change in enzyme activity (GOT) occurred during the 8-month period of storage at $-70^{\circ} \mathrm{C}$.

For the gluconeogenic enzyme assays in liver and kidney tissue, 26 ewes and 33 fetuses were studied. Thirteen ewes and 16 fetuses were sampled in the fed state and 13 ewes and 17 fetuses sampled in the fasted period. Mean gestational age was similar for each group (124.9 \pm 0.8 days). Mean fetal weight was decreased in fasting compared to fed $(2.86 \pm 0.56$ versus $3.61 \pm 0.58 \mathrm{~kg}, p<$ $0.001)$. When assayed per $\mathrm{g}$ of liver tissue or per $\mathrm{mg}$ of protein content, several gluconeogenic enzymes demonstrated a significant change in both maternal and fetal liver following a 5-day fast (Table 1). FDP, GP, and GPT all increased in both maternal and fetal liver with fasting. In addition, PEPCK and GOT both increased in fetal hepatic tissue. PC increased in maternal liver by almost 5 -fold, but demonstrated no significant change in the fetal compartment. PC activity was detectable only in the particulate fraction (mitochondria and nuclei) and was not present in the cytosolic portion.

PEPCK was assayed in both the cytosolic and particulate fractions. Of the $5.85 \mathrm{U} / \mathrm{g}$ tissue noted in maternal liver in the fed state, $92 \%$ were cytosolic and the remaining $8 \%$ were particulate. During fasting, $97 \%$ were cytosolic and $3 \%$ were particulate. In the fetal hepatic sample, $73 \%$ were cytosolic during the fed state, whereas during fasting $94 \%$ were cytosolic. No significant changes in distribution of the enzyme were noted.

Relatively few changes were noted in the kidney (Table 2). None of the enzymes changed significantly in maternal tissue. In the fetal kidney, FDP, GP, and GOT all increased significantly during fasting when calculated per $g$ of tissue. In the assay of PEPCK, the predominant component of this enzyme was again in the cytosolic fraction. In maternal kidney, $86 \%$ were cytosolic in the fed state. In the fetus a relatively higher particulate fraction was noted, in that $\sim 50 \%$ of the activity was mitochondrial in the fed state for the kidney. 
Table 1. Specific activities (U/g tissue) $\pm S D$ of each of the enzymes as measured in liver samples obtained during fed state and after 5 days of fasting

\begin{tabular}{lrrrrr}
\hline & \multicolumn{2}{c}{ Maternal } & & \multicolumn{2}{c}{ Fetal } \\
\cline { 2 - 3 } \cline { 5 - 6 } FDP & \multicolumn{1}{c}{ Fed } & Fasted & & Fed & Fasted \\
& 11.75 & $16.95^{*}$ & & 10.40 & $14.85^{*}$ \\
& \pm 2.11 & \pm 2.38 & & \pm 1.68 & \pm 2.14 \\
GOT & 115.55 & 117.38 & & 45.12 & $54.45 \dagger$ \\
& \pm 10.29 & \pm 10.20 & & \pm 7.55 & \pm 7.39 \\
GPT & 7.60 & $9.61 \dagger$ & & 4.38 & $6.82 \dagger$ \\
& \pm 1.69 & \pm 2.42 & & \pm 1.51 & \pm 2.53 \\
PC & 0.36 & $1.60^{*}$ & & 0.09 & 0.07 \\
& \pm 0.15 & \pm 0.64 & \pm 0.07 & \pm 0.04 \\
PEPCK & 5.85 & 5.75 & & 0.93 & $1.84^{*}$ \\
& \pm 2.41 & \pm 1.88 & \pm 0.33 & \pm 0.56 \\
G6P & 15.11 & 21.29 & 2.62 & $5.51^{*}$ \\
& \pm 1.83 & \pm 4.70 & \pm 1.37 & \pm 2.17 \\
\hline
\end{tabular}

$*$ Level of significance $<0.001$ for difference between fed and fasted states using Student's $t$ test.

$\uparrow$ Level of significance $<0.05$ for difference between fed and fasted states using Student's $t$ test.

Table 2. Specific activities (U/g tissue) $\pm S D$ of each of the enzymes as measured in kidney samples obtained during fed state and after 5 days of fasting

\begin{tabular}{|c|c|c|c|c|}
\hline & \multicolumn{2}{|c|}{ Maternal } & \multicolumn{2}{|c|}{ Fetal } \\
\hline & Fed & Fasted & Fed & Fasted \\
\hline FDP & $\begin{array}{r}5.48 \\
\pm 1.53\end{array}$ & $\begin{array}{r}6.57 \\
+1.61\end{array}$ & $\begin{array}{r}0.92 \\
\pm 0.14\end{array}$ & $\begin{array}{c}1.42^{*} \\
\pm 0.37\end{array}$ \\
\hline GOT & $\begin{array}{r}29.66 \\
\pm 4.55\end{array}$ & $\begin{array}{r}31.09 \\
\pm 4.43\end{array}$ & $\begin{array}{r}13.72 \\
\pm 2.05\end{array}$ & $\begin{array}{c}15.59 \dagger \\
\pm 2.15\end{array}$ \\
\hline GPT & $\begin{array}{r}3.79 \\
\pm 0.89\end{array}$ & $\begin{array}{r}4.04 \\
\pm 0.93\end{array}$ & $\begin{array}{r}2.44 \\
\pm 0.60\end{array}$ & $\begin{array}{r}2.75 \\
\pm 0.81\end{array}$ \\
\hline PC & $\begin{array}{r}0.81 \\
\pm 0.28\end{array}$ & $\begin{array}{r}0.96 \\
\pm 0.46\end{array}$ & $\begin{array}{r}0.19 \\
\pm 0.06\end{array}$ & $\begin{array}{r}0.19 \\
\pm 0.10\end{array}$ \\
\hline PEPCK & $\begin{array}{r}8.29 \\
\pm 2.66\end{array}$ & $\begin{array}{r}9.56 \\
\pm 1.65\end{array}$ & $\begin{array}{r}0.93 \\
\pm 0.35\end{array}$ & $\begin{array}{r}0.91 \\
\pm 0.31\end{array}$ \\
\hline G6P & $\begin{array}{r}16.57 \\
\pm 4.31\end{array}$ & $\begin{array}{r}19.32 \\
\pm 4.62\end{array}$ & $\begin{array}{r}2.56 \\
\pm 0.63\end{array}$ & $\begin{aligned} & 3.24 \dagger \\
\pm & 0.92\end{aligned}$ \\
\hline
\end{tabular}

* Level of significance $<0.001$ for difference between fed and fasted states using Student's $t$ test.

$\dagger$ Level of significance $<0.05$ for difference between fed and fasted states using Student's $t$ test.

\section{DISCUSSION}

Ruminant species such as the sheep rely almost exclusively on gluconeogenesis rather than intestinal glucose absorption to meet their glucose requirements $(11,12)$. The major precursors for glucose production in the normally fed ewe include proprionate $(40 \%)$, lactate $(15 \%)$, amino acids $(35 \%)$, and glycerol $(10 \%)$. During fasting for 3 to 5 days, hepatic glucose synthesis decreases by approximately $40 \%$ of fed state values, which is reflected by a fall in the plasma glucose concentration. During this time, proprionate becomes a negligible contributor to glucose synthesis, whereas gluconeogenesis from lactate and amino acids continues at approximately fed state values. Increased fatty acid catabolism and ketogenesis provide additional oxidative substrate for maternal tissues during fasting.

Results of the present study would suggest an augmented potential for gluconeogenesis in the fasted pregnant ewe, as four of the six enzymes assayed increased in activity in adult liver tissue. It should be emphasized that interpretation of changes in enzyme activities must be undertaken with caution, as such in vitro measurements may not reflect the rate of substrate flux in vivo. A previous investigation by Filsell et al. (13) in adult ewes, pregnant and nonpregnant as well as fed and fasted, yielded findings similar to ours (13). According to these authors, specific activities of each of the gluconeogenic enzymes (with the exception of PC) increased significantly in liver following 5 days of fasting. In the present study minimal changes in enzyme activity were noted in the adult kidney, perhaps reflecting the relatively small contribution of renal gluconeogenesis to total glucose production by the ewe. In the normal fed state approximately 10 to $15 \%$ of the glucose turnover is accomplished within the kidney (11).

The exogenous supply of glucose to the fetus decreases in direct proportion to the fall in maternal arterial glucose levels during the fasted period (2). However, oxidative requirements remain at approximately fed state levels within the fetus (3). Indirect evidence (i.e. a doubling in fetal urea production) suggests that amino acid catabolism may serve as alternate substrate to offset the decreased exogenous supply of glucose during maternal hypoglycemia (14). Free-fatty acids and ketoacids do not appear to contribute significantly to oxidative metabolism in the fetus during either the fed or fasted states (15).

While substrates such as amino acids may be oxidatively catabolized, there is still considerable debate regarding the ability of the ovine fetus to perform new glucose synthesis from these potential glucose precursors. Fetuses of several animal species have been found to have the enzymatic capability of new glucose production $(5,16,17)$. However, the relevance of these in vitro enzyme measurements to in vivo physiologic events is not known with certainty. Utilizing steady state infusion of tracer precursors in the sheep fetus (e.g. alanine, lactate), Hay et al. (1) have demonstrated new glucose production within the fetus in response to decreasing maternal and total glucose concentrations. During the fed state, the exogenous supply of glucose from the mother to the fetus appears to be adequate to meet glucose utilization rates. However, as this supply falls during fasting, the fetus appears to compensate by increasing glucose production endogenously from other substrate. These data were obtained from relatively few studies and are thus rather preliminary. On the other hand, Anand et al (18), utilizing similar methodology, found no evidence of fetal gluconeogensis during short-term insulin infusions which induced hypoglycemia in adult pregnant ewes (although these data were complicated by the fact that glucose and fructose were not separated prior to analysis). However, the majority of studies would appear to support the ability of the ovine fetus to perform gluconeogenesis, particularly as reflected by the presence of the necessary enzymes during relatively early gestation.

The present data cannot confirm whether the ovine fetus actually performs increasing rates of gluconeogenesis during the fasting period. The necessary enzymes are present and five of six (with the exception of pyruvate carboxylase) appear to increase in specific activity per $\mathrm{g}$ of tissue during the 5-day fasting period. Previous investigators have found higher levls of PC activity in the fetal lamb liver during normal gestation than we demonstrated (19). The reasons for the differences in the results are not apparent. Further, it is not known whether the low activity level of PC is rate limiting for gluconeogenesis in the fetal lamb. Most enzymes are functioning at levels far below their maximum capabilities, usually limited by substrate availability. Whether 
this is the case for the fetal gluconeogenic enzymes is not known. In an analogous study of the urea synthesizing capability of the ovine fetus, results similar to those of the present study were obtained, i.e. an increase in several urea cycle enzymes was noted in fetal liver during a 5-day maternal fast (20). However, urea production rates by the ovine fetus can more than double during an acute ammonia infusion (before time for actual enzyme induction has elapsed). Therefore, an increase in enzyme activity as measured in vitro would not appear to be a requisite for a change in physiological function, i.e. increased urea synthesis.

\section{REFERENCES}

1. Hay WW Jr, Sparks JW, Quissell BJ, Battaglia FC, Meschia G 1981 Simultaneous measurements of umbilical uptake, fetal utilization rate, and fetal turnover rate of glucose. Am J Physiol 240:E662-E668

2. Hay WW Jr, Sparks JW, Wilkening RB, Battaglia FC, Meschia G 1984 Fetal glucose uptake and utilization as functions of maternal glucose concentration. Am J Physiol 246:E237-242

3. Lemons JA, Schreiner RL 1983 Amino acid metabolism in the ovine fetus. Am J Physiol 244:E459-E466

4. Prior RL 1982 Gluconeogenesis in the ruminant fetus: evaluation of conflicting evidence from radiotracer and other experimental techniques. Fed Proc 41:117-122

5. Stevenson RE, Morriss FH Jr, Adcock EW III, Howell RR 1976 Development of gluconeogenic enzymes in fetal sheep liver and kidney. Dev Biol 52:172

6. Wagle SR 1966 Studies on activities of gluconeogenic enzymes in sheep liver. Biochim Biophys Acta 121:190-191

7. Fiske $\mathrm{CH}$, Subbarow Y 1925 The colorimetric determination of phosphorus. $J$ Biol Chem 66:375-400
8. Latzko E, Gibbs M 1974 Alkaline $C_{1}$-fructose-1,6-diphosphatase. In: Bergmeyer HR (ed) Methods of Enzymatic Analysis, Vol II. Academic Press, New York, pp 881-884

9. Ballard FJ, Hanson RW 1967 Phosphoenolpyruvate carboxykinase and pyruvate carboxylase in developing rat liver. Biochem J 104:866-871

10. Bergmeyer HU, Bernt E 1974 Glutamate-oxaloacetate transaminase and glutamate-pyruvate transaminase. In: Bergmeyer HU (ed) Methods of Enzymatic Analysis, Vol II. Academic Press, New York, pp 727-773

11. Bergman EN 1973 Glucose metabolism in ruminants as related to hypoglycemia and ketosis. Cornell Vet 63:341-382

12. Baird GD 1977 Aspects of ruminant intermediary metabolism in relation to ketosis. Biochem Rev 5:819-827

13. Filsell OH, Jarrett IG, Taylor PH, Keech DB 1969 Effects of fasting, diabetes and glucocorticoids on gluconeogenic enzymes in the sheep. Biochim Biophys Acta 184:54-63

14. Simmons MA, Meschia G, Makowski EL, Battaglia FC 1974 Fetal metabolic response to maternal starvation. Pediatr Res 8:830-836

15. Schreiner RL, Burd LI, Jones MD Jr, Lemons JA, Sheldon RE, Simmons MA Battaglia FC, Meschia G 1978 Fetal metabolism in fasting sheep. In: Longo L (ed) Fetal and Newborn Cardiovascular Physiology. Garland, New York, pp 197-222

16. Prior RL, Scott RA 1977 Ontogeny of gluconeogenesis in the bovine fetus: influence of maternal dietary energy. Dev Biol 58:384-393

17. Jones CT, Ashton IK 1976 The appearance, properties, and functions of gluconeogenic enzymes in the liver and kidney of the guinea pig during fetal and early neonatal development. Arch Biochem Biophys 174:506-522

18. Anand RS, Ganguli S, Sperling MA 1980 Effect of insulin-induced maternal hypoglycemia on glucose turnover in maternal and fetal sheep. Am J Physiol 238:E524-E532

19. Warnes DM, Semark RF, Ballard FJ 1977 The appearance of gluconeogenesis at birth in sheep. Activation of the pathway associated with blood oxygenation. Biochem J 162:627-634

20. Lemons JA, Snodgrass PJ 1985 The effect of a maternal fast on the urea cycle enzymes of the ovine fetus. J Pediatr Gastroenterol Nutr 5:138-142 